\title{
Research on Social Conflicts of the Old-caring Villages under the Background of Industrial Transformation
}

\author{
Yuan Fang ${ }^{1}$ a; Wang-ming $\mathrm{Li}^{1}$; Li-xiong Zhu ${ }^{1}$ \\ ${ }^{1}$ B617 An-zhong Building, Zijingang campus, Zhejiang University, Hangzhou City, Zhejiang \\ Province, China
}

a120361565@qq.com

\begin{abstract}
Keywords: Industrial Transformation; Old-caring Village; Social Conflict
Abstract. Industry transformation is the main development process of rural modernization and new urbanization. The huge changes of social, economic and cultural caused by rural industry transformation have shocked the social order, values and other aspects of the village, leading to various direct or indirect conflicts in the rural society. Based on the field investigation of 15 old-caring villages in Hangzhou, china, this paper makes a deep study of the changing characteristics of rural society and the formation and evolution mechanism of social conflicts under the background of industrial transformation, finds that responsibility fuzzy boundaries, the unbalanced distribution of interests, imperfect industrial chain and unclear understanding of the basis of development are causes of social conflict, then puts forward the optimization strategy of dealing with social conflicts and promoting organic unity in the aspects of economic service management system, industrial division of labor, infrastructure and so on.
\end{abstract}

\section{Introduction}

In the development trend of new urbanization characterized by urban and rural integration, the pace of China's rural modernization has gradually accelerated, and the trend of non-agricultural industrial structure has become increasingly distinct. As an important way of rural modernization, industrial economic transition has become the development goal of rural society ${ }^{[1]}$. Rural industrial transformation includes a variety of ways of modern agriculture transformation ${ }^{[2]}$, industrial transformation $^{[3]}$, leisure tourism industry transformation ${ }^{[4-5]}$, the transformation and resources utilization in different ways, but their influences on the village social solidarity are in common. The transformation of village industry has a great promotion to the economic level of villages and villagers. However, the resulting changes of social, economic and cultural will impact on all aspects of the production, life, consumption and values, thus forming the rural social solidarity imbalance, there may even be a direct or indirect conflict ${ }^{[6-7]}$. While the social conflict has positive social function and negative social function ${ }^{[8]}$, so, understanding the formation mechanism of rural social solidarity and the causes of the conflict, promoting the positive social function and reconstructing social solidarity are the most important issues in the rural development research under the background of industrial transformation.

This paper takes the Old-caring Villages in the transition of leisure tourism as an example. On the basis of on-the-spot investigation of 15 Old-caring Villages in Hangzhou, China, use interview, questionnaire survey and other research methods, found that various changes in the process of rural social and the causes of social conflicts under the background of the industry transformation, and put forward the optimization strategy to deal with social conflicts and rebuild social unity.

\section{Main Influence of Industrial Transformation on Rural Society}

\section{Labor Mode}

In the Old-caring Villages, the main work mode of the villagers is changed from "agriculture for all" to "service oriented" and "plural labor coexist". The prototype of the characteristic village is mostly the ecological village with excellent ecological environment, but backward economy and 
inaccessible traffic. The working mode of the villagers is mostly the farming, gathering and rough processing models with the characteristics of "Look at the sky for dinner, labor intensity, low economic returns". Some villagers go to big cities to find jobs with high pay, while more villagers start the pension service in the trend of rural tourism. Such as village B in Ling'an, Hangzhou, labor is dominated by cutting down trees, charcoal and other original ways before 2000 . However, with the strengthening of the ecological consciousness and the rapid development of the service industries, such as farmhouse, health and pension, more and more labor force began to engage in the service work of farmhouse, leisure tourism and pension services after 2000.

\section{Economic Income}

With the transition from a small-scale peasant economy to a service economy, the overall economic level of the village has been greatly improved. Fig. 1 shows that the annual per capita income of village B increased rapidly from 3804 RMB in 1998 to over fifty thousand RMB in 2014, and the per capita income increased by more than 13 times during the 16 years. The impact of industrial transformation on the economic income of villages is so enormous that about $65 \%$ of them come from the third industry. With the change of villagers' labor mode from the traditional single farming to the modern diversification, the division of labor will inevitably lead to different income returns. Just as the city's skilled workers and manual workers are not only entirely different in their labor input, but their returns are also quite different. In the villages, the difference in the rate of return on investment is reflected in the way villagers work, resulting in a gradual increase in the income gap of villagers.

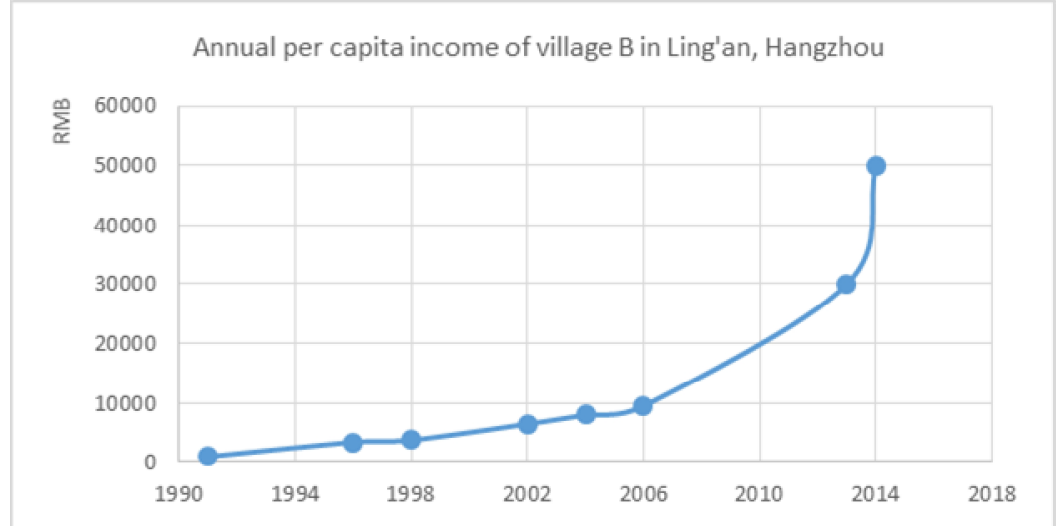

Note: 1991-2006 years of data came from the literature ${ }^{[9]}, 2014$ and 2016 data from field interviews

Fig.1. Annual per capita income of village B in Ling'an, Hangzhou

\section{Social Structure}

In addition to the agglomeration of production resources, the transformation of rural industries is accompanied by an influx of population. A large number of immigrants dilute the traditional social structure of local society based on the relationship of "human feelings" and "kinship". Investment developers, migrant workers, external consumer groups and other roles will even lead to changes in the role of villagers and traditional social strata. At the same time, because of the market sensitivity and action ability leads to different income differences, "seize the first chance will often bring more opportunities" ${ }^{[10]}$, the first one try to transition become the leader of the ordinary villagers. The general villagers' dependence on the collective and the elite of the village decreased significantly. Such as the village $T$ in Tonglu, Hangzhou, the Old-caring industry started by a small amount of villagers. With the rapid development of industry, this part of the villagers accumulated a large number of tourists, and become the actual leader of the village pension industry. In the later stage, the operators who join the pension industry must rely on that part of villagers.

\section{Various Conflicts under the Influence of the Transition}

\section{Group Conflict under Egoism}

Households vs Households: Low Price Competition Disrupted the Pension Market

The economic development base of characteristic villages is generally weak, and the villagers' cultural level and management consciousness are not high, so there are many problems in the process 
of development, such as single management mode, low service capacity and less attractive features. Households can only increase their competitiveness by constantly lowering prices. In the vicious competition, the phenomenon slander and even direct conflict among the individual households left a bad impression on the urban elderly. This kind of unreasonable low price competition not only leads to low service quality and low satisfaction among the elderly, but also leads to the confusion and low end of the whole pension market, which has a devastating impact on the entire pension industry.

Village vs Households: Tourist Exclusive Hinder the Transformation of Village

The choice of elderly villages in the urban elderly generally depends on the publicity and recommendation of experienced older people around them. At the same time, the elderly are relatively loyal to the households and will not choose other households when the service is good. This asymmetric information between buyers and sellers leads to a huge gap between customers. The early households gradually accumulated a large number of tourists, while the late ones were depressed. According to Olsen's theory of collective action, rational households may not give up their own interests for the collective development. As a result, even though the early developers were overloaded with pressure, they were reluctant to hand over their tourist resources to the village community for distribution or sharing to other operators. This situation of a small number of people occupied most of the resources has greatly affected the administrative prestige of the village committee, blocked the transformation process of the village committee, and affected the overall development of the village to a considerable extent.

External Developers vs Villagers: Lack of Trust Caused the Increase of Resistance

The developer chooses a village to become the carrier of the pension industry after inspection, put in economic cost and manpower costs, and built a comfortable environment for the aged. This is a resource exchange for the chosen village. That is, the village will sell or share the ecology, climate and other environmental resources temporarily unavailable, and obtain a one-time or long-term return on funds. This exchange seems to be fair, but no one knows exactly the value of environmental resources, so the villagers always in a mood swing worry about personal gains and losses. Under the influence of this emotion, the villagers' attitudes and expectations toward developers are rather delicate. On the one hand, the villagers hope that the developers will succeed and promote the development of the village; on the other hand, they are worried that the development of the pension industry is too successful, and the benefits they have gained are relatively low. Relatively speaking, the interests of the villagers and developers tend to be consistent. However, when the credibility of the village committee is weak, the villagers are even worried that their interests will be betrayed by the village committee, thus ignoring and even resisting the development of the pension industry.

\section{Policy Breakthrough by Profit Driven}

The old-caring Villages are generally located in high altitude mountains or canyons. The large slopes resulted in the scarce of cultivated land and land resources suitable for construction. According to the "Zhejiang rural homestead management approach", a rural villager can only have a homestead, and the highest area shall not exceed 160 square meters. But the residence in the old-caring Villages has the demand of living and management, so the overall demand for housing scale is higher than that of the ordinary village. At the same time, the larger the size, the more room, the greater the economic benefits, therefore, expanding housing area and raising operating income are the general needs of the villagers. Driven by economic interests, the farmers have made great conflicts with the building land policy and the cultivated land protection policy. The phenomenon of housing size exceeds the standard and illegal structures continue to occur, not only affects the village of traditional style, breakthrough the rural housing policy, but also the wrong demonstration to other farmers.

\section{High Intensity Business Activities Lead to Environmental Pollution}

The development of the old-caring Villages depends on its excellent ecological environment and cool climate conditions, such as high altitude, low temperature in summer and strong negative ion concentration. However, it is easy for pension management to have a negative impact on these scarce natural resources. With the expansion of the pension industry, the number of the elderly and the intensity of the old-age management activities are both increasing. The increasing number of tourists 
and the elderly directly led to the increase of sewage, garbage and other pollutants, however, the backward and inefficient of village infrastructure has resulted in many environmental problems such as water pollution, noise pollution, damage to the local environment, which affect the sustainable development of the pension industry village.

\section{Analysis of the Conflict Causes}

\section{Blurred Power and Responsibility, Unreasonable Distribution of Benefits}

The transformation of village industry is not only a material change of the leading industry from the primary industry to the second and third industries, but also a non-material change of social structure, mode of thinking and concept of consciousness. In the final analysis, the social conflicts in the process of industrial transformation are the imbalance between the allocation of resources and the distribution of benefits caused by the blurring of the power and responsibility boundaries in the process of economic interest redistribution. How to redistribute benefits is the root of game and competition among different subjects. Driven by interest, ordinary villagers, business households, village committees and investment developers are trying to maximize their own interests and minimize costs. This leads to the phenomenon of free riding, vicious competition, excessive exploitation of resources, policy breakthrough and enterprise rent-seeking.

\section{Low Added Value, Imperfect Upstream and Downstream Industry Chain}

The development of rural pension industry is similar to other service industries. It needs not only sufficient labor force, but also perfect industrial chain system and supporting facilities. Ordinary villagers due to the low level of knowledge, only to see a substantial profit pension industry to bring the itch to try, leading to the rural pension industry herd situation. Lack of understanding and weak management consciousness lead villagers to copy the development path and successful experience. Most of the households lack the emergency experience and innovation ability, which leads to the appearance of a single form of extensive pension industry in the regional level, the scarcity of operating characteristics, and the fracture of the upstream and downstream industry chains. The added value of pension services is very low. In this state, business users can only through lower prices, expanding the scale of the reception and other ways to increase competitiveness, but this approach will inevitably lead to reduce the quality of service pension, if things go on like this easy to form a vicious spiral, caused a fatal blow to the rural pension industry.

\section{Unclear the basis of development}

The old-caring Villages originated from rural tourism. Cool climate and good ecological environment are the most important development base for the old-caring Villages. However, the development of the pension industry blindly pursues high returns, ignoring the problems of sewage treatment, garbage collection and tidiness of public areas, resulting in environmental overload, water pollution and crop disturbances. These phenomena of lack of self-discipline consciousness and management consciousness are undoubtedly the villagers' lack of clear and profound understanding of the basis of the development of the old-caring Villages.

\section{Explore Ways to Rebuild Social Solidarity}

\section{Strengthen the Economic Service Capacity of the Village Committee and Perfect the Management System}

Relying on the villagers to develop their own pension industry, there are problems such as weak financial strength, lack of professional business knowledge and broad vision. In order to improve the villagers pay more attention to the development of villages, the most convenient and effective way is the link by the economic interests of the villagers and the village will be bundled together to form clear rights and obligations of the contract, so as to balance the interests of individual income. In this case, the village committee should accelerate the transformation of strengthening economic core services, the establishment of team dedicated to business management, raising funds to achieve capital intensive investment, introducing advanced technology and mode, promote the pension 
industry to the formation of high value-added industrial system.

\section{Promote the Division of Labor, Extend the Industrial Chain}

In order to avoid all kinds of unnecessary competition, both the regional and village levels should be considered industrial dislocation and characteristic development, while speeding up the extension of upstream and downstream industry chain, enriching tourism projects and promoting economic value added. In the process of village industry development, we should first refine the industrial division of labor, and establish a mechanism of division of labor and coordination on the whole level, and make clear the limits of power and responsibility. Secondly, we should take the new industry as the leading factor, speed up the development of supporting industries in the upper and lower reaches, and make full use of the surplus labor force in the villages to prevent vicious competition.

\section{Attach Importance to the Environment and Improve Infrastructure Construction}

There is a saying "beautiful scenery is gold and silver", the ecological environment is the basis for the development of the old-caring Villages. Therefore, the industrial economy should not be developed at the expense of destroying the environment. In order to prevent the scale exceed the capacity of the environment, industrial restructuring should be set to control the size and development of the incentive mechanism on the basis of the strict control, the area of the homestead and rural housing construction standards, and to collect fees paid for the use of the form of super high buildings have been built in the limit of economic sanctions. At the same time, we will improve infrastructure construction, timely deal with pollutants, achieve comprehensive sewage interception and disposal, and uniformly manage waste collection and treatment to ensure the clean appearance of the villages.

\section{References}

[1] Wang Mengxue. Study on the transformation of modern rural economy [D]. Zhejiang Normal University, 2014.

[2] Liu Wuhua, Zhao Jiangyan. To promote the rural economy in Shanxi Province Development Countermeasures [J]. Chinese Trade Herald, 2010, (10): 36-38. [2017-08-08].

[3] Qiao Jiajun, Zhao Dehua, Li Xiaojian. Industrial development of the village economy influence temporal evolution -- Survey of Gongyi City Huiguo town 21 village based on the [J]. analysis of economic geography, 2008 (04): 617-622. [2017-08-08]. DOI:10.15957/j.cnki.jjdl.2008.04.028

[4] Huang Xijia, Song Lijuan, Huang Mojun. On rural leisure and the transformation of rural economy to promote the role of the [J]. commercial era, 2009, (11): 109-110. [2017-08-08].

[5] Ma Hongliang. Study on Countermeasures to speed up the transformation and upgrading of agricultural economy in Anji [J]. China Agricultural Mechanization, 2010, (04): 94-97. [2017-08-08].

[6] Song Xiaohong. New period of change of interest to the socialist ideology and challenge to the theory of $[\mathrm{J}]$. education Herald, 2016, (05): 84-88. [2017-08-08]. DOI:10.16580/j.sxlljydk.2016.05.014

[7] Hou Hongxia. Conflict and adjustment of village power order in transition [J]. vicissitudes of life, 2009, (02): 109-110. [2017-08-08].

[8] Lewis, A., Coser., The, Functions, of, Social, Conflict, [M]., London, Free, Press, 1956, Preface.

[9] Zhang Wenjie, Shen Yueqin, Cai Yingping. A case study of coordinated development of eco economy in the construction of new rural areas in mountainous areas. Take Baisha village, Taihu town as an example, [J]., East China forest manager, 2008, (01): 9-14. [2017-08-08].

[10]Zhao Xiaofeng, Lin brilliant. Village rich social absorptive mechanism and political exclusion function -- Investigation [J]. Journal of Ningbo municipal Party School of Zhejiang Pioneer Village young farmers Village Elite practice, 2010,32 (04): 33-41. [2017-08-08]. 